\title{
ІМПЛЕМЕНТАЦІЯ МОНІТОРИНГОВИХ ТЕХНОЛОГІЙ КОНТРОЛЮ СТАНУ ЗДОРОВ'Я ПАЦІЕНТВ ДЛЯ НАСЕЛЕННЯ ТЕРИТОРІАЛЬНИХ ГРОМАД
}

Харковлюк-Балакіна Н. В., к.б.н. natabalakina74@meta.ua

ДУ "Інститут геронтології ім. Д. Ф. Чеботарьова НАМН України"

Горго Ю. П., професор, д.б.н.

yugorgo@ukr.net

Національний технічний університет України "Київський політехнічний інститут імені Ігоря Сікорського"

Медвидчук К. В.

kvastrin@gmail.com ДУ "Інститут геронтології ім. Д. Ф. Чеботарьова НАМН України"

м. Київ, Україна

\begin{abstract}
Реферат - Визначено провідні позииії стосовно контроля здоров'я населення територіальних громад. Обтрунтовано ефективність використання передових інформаційно-комунікаційних технологій дистанційного моніторингу стану здоров'я пацієнтів для осіб, що проживають у сільській місцевості, а також осіб з хронічними патологіями, які мають високий рівень медичної потреби. Досліджено досвід використання "розумних" технологій у медичній галузі для вирішення завдань профілактики вікових хвороб та прискореного старіння населення.
\end{abstract}

Ключові слова - системи дистанційного моніторингу здоров'я пацієнтів, інформаційно-комунікаційні технології в медицині, контроль здоров'я, управління охороною здоров'я на регіональному рівні.

\section{I. ВСТУП}

Сучасні демографічні дані свідчать про постійне зростання кількості осіб похилого віку в загальній структурі населення. За даними ООН кількість людей віком від 60 років глобально зросте до 2 млрд. до 2050 р. Тенденцію до поширення з віком мають певні захворювання, такі як серцево-судинні патології, діабет, остеоартрит або інші хронічні захворювання, в поєднанні 3 природним прогресуючим зниженням фізичних i когнітивних навичок. Натомість якісна медична допомога не завжди $\epsilon$ доступною для населення територіальних громад. Це $\epsilon$ визначальним фактором для реформування системи охорони здоров'я на сучасному етапі розвитку країни. Ключовим інструментом модернізації виступають системи контроля здоров'я населення, які мають міжнародний досвід впровадження.

\section{II. МЕТА ДОСЛІДЖЕННЯ}

Метою роботи було провести аналіз моніторингових систем, які орієнтовані на контроль здоров'я пацієнтів, дослідити сучасні системи дистанційного моніторингу здоров'я пацієнтів, які інтегрують технології веб-, мобільного- та смарт-модулів для оптимізації управління охороною здоров'я на регіональному рівні.

\section{III. РОЗУМІННЯ СУТНОСТI ПОНЯТТЯ ЖИТТЕЗДАТНОСТІ ЛЮДИНИ ФАХІВЦЯМИ РІЗНИХ \\ ГАЛУЗЕЙ НАУК ДЛЯ ВИЗНАЧЕННЯ ПРОВІДНОЇ ПОЗИЦІї КОНТРОЛЯ}




\section{ЗДОРОВ'Я НАСЕЛЕННЯ ТЕРИТОРІАЛЬНИХ ГРОМАД}

На думку основоположника валеології Ізраїля Брехмана саме здоров'я людей повинно служити головною "візитною карткою" соціально-економічної зрілості, культури й успіху держави. Водночас, у літературі немає єдиної думки про критерії рівня здоров'я населення територіальних громад. Між тим, й на сьогодні здоров'я як явище і стан організму представляє інтерес для фахівців різних країн та галузей науки (Baig \& Gholamhosseini, 2013; Solanas et al., 2014; J. Offermannvan Heek, Martina Ziefle, Simon Himmel, Alexander Hörbst, 2019). Наразі, актуальність конкретизації поняття здоров'я різко зросла починаючи з середини XX ст. в період створення Всесвітньої Організації Охорони Здоров'я (Женева).

За визначенням, в основі здоров'я лежать цілком об'єктивні процеси, які відображають стан, що відчувається людиною суб'єктивно та фізично [1, 2, 3]. Отже, справедливим $\epsilon$ твердження, що здоров'я це життєздатність в іï суб'єктивно сприйманому вираженні $[4,5]$. Відповідно до сучасних визначень, здоров'я це не відсутність захворювань, патологічних станів або фізичних дефектів, а, як підкреслював Г. Сигерист, деяка визначеність, що не зводиться до відсутності хвороб. Таке розуміння здоров'я послужило основою для дефініції, прийнятої ВООЗ: "Здоров'я - цей стан повного фізичного, душевного i соціального благополуччя, a не тільки відсутність хвороби або фізичних дефектів". За роки, що пройшли після публікації цієї дефініції здоров'я, багато дослідників зверталися до неї, відмічаючи іiі невизначеність і непридатність відносно рішення практичних завдань моніторингу (Passmore, 1979; Eckholm, 1987; В. Войтенко, 1991; Р. Баєвський, 1999; М. Амосов, 2002; Г. Апанасенко, 2010; S. Spinsante, E. Gambi, 2012; P. Bagga, R. Hans, 2015) [6].

Проте, існують наукові дані, які дозволяють відокремити стан здоров'я від протилежного стану — хвороби. За розповсюдженим визначенням, здоровою може вважатися людина, яка відрізняється гармонійним фізичним i розумовим розвитком i добре адаптована до навколишнього фізичного i соціального середовища. За визначенням Г. Сигериста особа, яка повністю реалізує свої фізичні і розумові здібності, може пристосовуватися до змін навколишнього його фізичного i соціального середовища, якщо вони не виходять за межі норми.

На сьогоднішній день у міжнародній базі даних зустрічаються різноманітні онлайн системи моніторингу та збору даних про здоров'я та фізичний стан пацієнтів, які відіграють ключову роль у розвитку сучасних систем охорони здоров'я. Такі інформаційнокомунікаційні технології довели свою ефективність, особливо коли процес спостереження за станом здоров'я та лікування включає моніторинг деяких життєвих параметрів протягом тривалого періоду часу.

Концептуально моніторинг та оцінка здоров'я людини базується на відображенні взаємозв'язків між життєздатністю і іiі самооцінкою. Отже, здоров'я, як і цілий ряд інших медико-біологічних понять (життєздатність, адаптивність), є абстрактнологічною категорією. Теоретичний аналіз сутностей, що відповідають цим поняттям, тим більше практичний вимір цих сутностей можливі тільки за допомогою моделей $[1,2$, $6]$.

Водночас, самооцінка здоров'я істотно видозмінюється в процесі індивідуального життя людини. Ось чому такі різні самооцінки власного здоров'я людей навіть 3 схожим рівнем життєздатності і функціонального стану організму. Таким чином різко виражена суб'єктивність і емоційність в сприйнятті життєздатності створюють непереборну перешкоду для вибору об'єктивних критеріїв моніторингу та оцінки стану здоров'я людини [6].

Наукові факти свідчать про те, що один i той же рівень життєздатності оцінюється по-різному в його суб'єктивних і об'єктивних проявах [6, 7]. Наприклад, 
існують порушення функціонального стану організму, які не супроводжуються суб'єктивними відчуттями. Такі фактори ризику і початкові стадії більшості хронічних неспецифічних, тобто неінфекційних, захворювань: атеросклерозу, гіпертонічної та ішемічної хвороби серця. "Непомітними" для самого хворого виявляються також деякі досить серйозні захворювання. Всі ці порушення i захворювання мають в своїй основі явні ознаки стану зниженої життєздатності, однак людина, їх не відчуває на початковій стадії. Таким чином, суб'єктивне i об'єктивне сприйняття життєздатності організму i різних функціональних станів його можуть істотно відрізнятися. (за фізіологічним законом сприйняття Вебера-Фехнера) (рис. 1) [6].

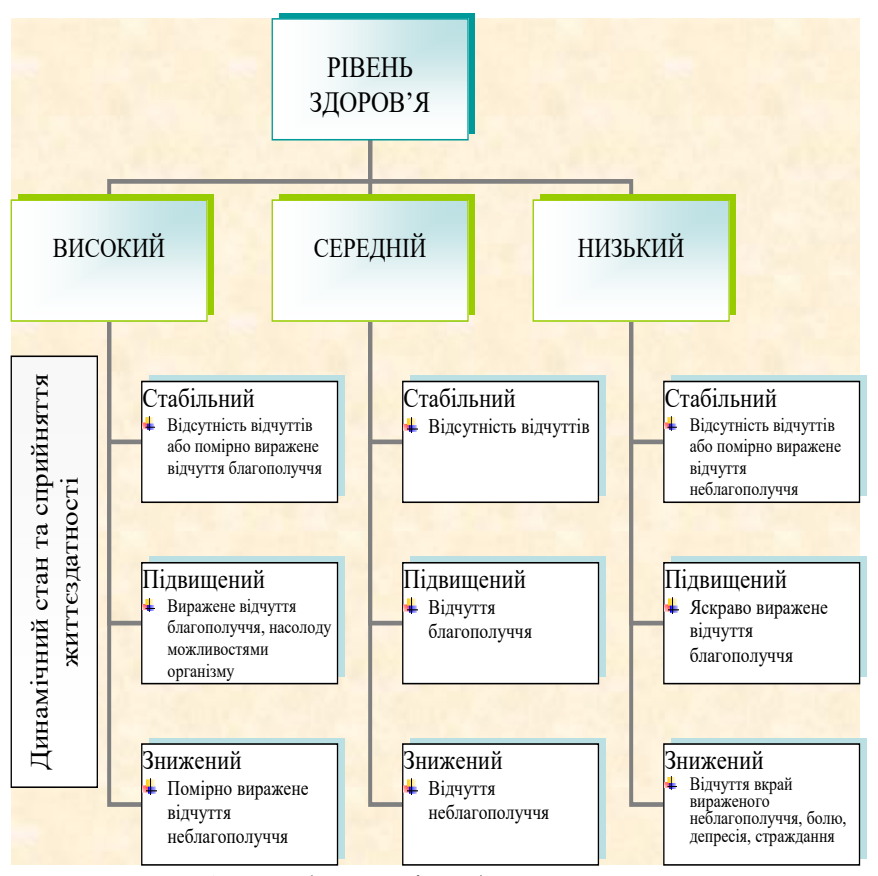

Рис. 1. Особливості суб'єктивного сприйняття життєздатності і її змін при різних рівнях стану здоров'я (Муравов І., Буліч Е, 2013).

Наразі, сприйнятя рухової недостатності (гіпокінезії) найчастіше суб'єктивно не викликає у людини дискомфортні відчуття, а навпаки, людина все більше звикає, та адаптується до цього шкідливого стану, замість того, щоб чинити опір йому.
Подібна ситуація спостерігається i щодо харчування, у більшості випадків воно надлишкове та перевищує потреби організму, що збільшує ризик захворювань, однак сприймається як комфортний стан. Отже, використання традиційних критеріїв самооцінки здоров'я не завжди відображає фізіологічний механізм об'єктивного функціонального стану людини.

Стосовно поняття "моніторинг" на сьогодні відомі різні теоретико-методологічні аспекти щодо трактування цього поняття. Моніторинг дозволяє системно досліджувати будь-який процес і його об’єкти 3 метою отримання достовірної інформації для ефективного управління процесами, програмами розвитку i т. п.. Таким чином, моніторинг в загальнонауковому розумінні це діяльність, яка передбачає діагностику, контроль і прогнозування, які $є$ важливими складовими системи управління. Така система охоплює всі рівні управління від державного, регіонального до рівня територіальних громад.

За аналізом зарубіжних джерел моніторинг у сфері охорони здоров'я відображає систему постійних спостережень, оцінки i прогнозу зміни стану об'єкту досліджень. Моніторинг в цілому розглядається 3 різних точок зору як засіб управління та як засіб оцінки ефективності управління якістю охорони здоров'я населення.

Останні досягнення в галузі комунікацій призвели до появи так званих "розумних" технологій. Однак, незважаючи на значні теоретичні напрацювання, i до цього дня не створена універсальна система контроля здоров'я населення територіальних громад. Окремі аспекти діагностики фізичного здоров'я, представлені в сучасних роботах зарубіжних дослідників, доводять ефективність використання так званих "Smart Health Monitoring Systems" - інтелектуальних систем моніторингу здоров'я (Р. Astrand, Т. Sjostrand, 2012; Baek, Chung, Kim; Ioannis Routis, Shanika Nanayakkara, Xiaoyan Zhou, 2014; Heiko Spallek, Marco Schweitzer, 2019). Однак, їх застосування в умовах України 
наштовхується на цілу низку проблем теоретичного, методологічного та прикладного характеру.

За видами завдання моніторинг включає наступні складові: інформаційну (збір, накопичення, систематизація та поширення інформації), базову (діагностика нових проблем до того, як вони будуть усвідомлені на рівні управління), проблемну (діагностика закономірностей, погроз, процесів, проблем, які вже відомі), управлінську (відстеження та оцінка ефективності наслідків і вторинних ефектів рішень, прийнятих у сфері управління).

Класифікація наступної групи моніторингу грунтується на наявних видах експертиз та досліджень, в результаті чого розрізняють динамічний (використовує дані про динаміку розвитку об'єкта, явища або показника), порівняльний (обираються результати подібних обстежень інших освітніх систем), комплексний (використовують кілька підстав для експертизи), безпідставний (для аналізу беруть результати тільки одного дослідження) моніторинг. Отже, моніторингові дослідження є надійним інструментом аналізу різноманітних аспектів процесу охорони здоров'я населення. Вони дозволяють отримати реальну картину результативності нововведень у медичній галузі.

Незважаючи на існуючі складнощі, моніторинг у сфері охорони здоров'я повинен відповідати вимогам наступних принципів: комплексність (спостереження за всіма основними процесами) i диференціація найважливіших параметрів здоров'я людини і критеріїв його оцінки; системність (ієрархічна взаємопов'язаність часткових i узагальнюючих показників, зокрема працездатності); однорідність досліджуваних об'єктів; адаптивність (система показників повинна відповідати державній статистичній звітності); стандартизація оцінок моніторингу [3]. У статуті Всесвітньої Організації Охорони Здоров'я зазначено, що уряди несуть відповідальність за здоров'я своїх народів, і ця відповідальність вимагає прийняття відповідних заходів соціального характеру в галузі охорони здоров'я. У цьому контексті, фахівців різних країн поєднує думка, що у науці відсутній об'єктивний опис ознак здоров'я людини.

Підсумовуючи

зарубіжний, доповнюючи вітчизняний науковий досвід можна констатувати, що під поняттям контроль здоров'я населення територіальних громад необхідно розуміти науково обгрунтовану систему періодичного збирання, узагальнення та аналізу інформації про стан фізичного, психологічного, соціального здоров'я людини, про потреби в його збереженні, про суб'єктивне усвідомлення і об'єктивне сприйняття життєздатності, мотиваціях до оздоровчого контролю й обов'язкове надання отриманих даних для прогнозування та прийняття рішень на всіх рівнях влади.

\section{IV. ПЕРЕДОВІ ІНФОРМАЦІЙНО- КОМУНІКАЦІЙНІ МОНІТОРИНГОВІ ТЕХНОЛОГІЇ КОНТРОЛЯ СТАНУ ЗДОРОВ'Я ПАЦІЕНТІВ}

Аналіз сучасного стану моніторингових систем, які орієнтовані на контроль здоров'я пацієнтів, дозволив відокремити ряд зарубіжних авторів, що зосереджують свою діяльність у цій галузі досліджень.

Концепція, що заснована на мобільній бездротовій сенсорній платформі (EIS Embedded Internet System) була запропонована групою зарубіжних авторів ще у 2003 році (Ostmark Ake et al., 2003) [8]. Принцип ii роботи дозволяє взаємодію користувачів на основі стандартної $\quad W W W$-браузерної технології. Сенсорна система діє як пристрій Bluetooth, який забезпечує TCP/IP інтерфейс для конфігурації та обслуговування.

Реалізацію та досвід роботи 3 системою телемедицини для моніторингу на основі WAP-бази запропоновано авторами Hung Kevin i Yuan-Ting Zhang [9]. Доступ до бази даних пацієнтів, зокрема для контролю артеріального тиску, електрокардіограми та інших життєвих параметрів передається для зберігання на WAP-пристрої. Водночас, 
авторизовані користувачі мають доступ до загальних даних пацієнтів.

Smart-телевізійну технологію для взаємодії пацієнтів та медичних працівників було запропоновано Sorwar G. i Hasan R. [10], яка базувалася на інтегрованій телемоніторинговій основі для підтримки процесу моніторингу стану здоров'я пацієнтів. Сенсорну технологію, інтегровану в домашній системі, яка контролює здоров'я пацієнтів, використовували дослідники Arcelus A. et al. [7]. Вони також запропонували інформаційну систему для обробки бази даних.

Для спостереження за змінами параметрів донозологічних станів та профілактики патологій автори Chan Marie et al. [11] зосередили свою увагу над розробкою мультисенсорної системи моніторингу. Розроблена технологія орієнтована на своєчасну допомогу літнім людям, які не мають підтримки з боку родичів та інших осіб.

Аналогічна система, яка забезпечує цілісне рішення, описана в роботі Agarwal Sparsh i Chiew Tong Lau [12]. Автори описали службу дистанційного моніторингу здоров'я, яка збирає показники артеріального тиску у пацієнта через мобільний телефон та робить ïx доступними для лікарів через вебінтерфейс.

Систему моніторингу здоров'я на основі смартфонів було розроблено дослідниками Yong L. et al. [13]. Для передачі даних на віддалений сервер охорони здоров'я, який може стежити за кількома користувачами в режимі реального часу, використовується 3G або Wi-Fi мережа.

Автори Sapal T. et al. [14] та Silva Bruno et al. [15] представляють вичерпну інформацію про огляд сучасних систем у програмах моніторингу здоров'я (m-Health) та пропонують нові технології для віддаленого догляду за пацієнтами, які є більш гнучкі і зручні у використанні.

За даними Jiuping $\mathrm{Xu}$, Lei $\mathrm{Xu}$ [16] до систем моніторингу здоров'я слід відносити сукупність заходів, що проводяться для оцінки структурної цілісності в режимі реального часу для функціонування системи інтегрованого управління здоров'ям (ISHM). Зазвичай системи дистанційного контролю здоров'я на основі телемедицини містять усі функціональні можливості системи віддаленої охорони здоров'я. Крім того, системи віддаленого моніторингу здоров'я вимагають постійного та безперебійного моніторингу параметрів здоров'я пацієнтів за допомогою розподіленої мережі датчиків.

Основна функція моніторингової системи полягає в постійному відстеженні стану здоров'я людей 3 різними його порушеннями, такими як хронічні захворювання та інвалідність, або з умовами, які потрібно контролювати (вагітність, перевірка після пологів, стан літніх людей тощо).

На рисунку 2 представлено схему моніторингу, оцінки та прогнозу стану здоров'я пацієнтів, на якій базуються інформаційно-комунікаційні технології контроля здоров'я людини. Слід відмітити, що принцип роботи будь-якої моніторингової системи базується на підтримці віддаленого процесу охорони здоров'я та забезпеченні інтерактивного спілкування між лікарем та пацієнтом.

Як правило, у представлених моніторингових системах $є$ три учасники: адміністратор, лікар та пацієнт. Система автоматично надсилає оновлення до центральної бази даних, які збираються на основі даних вимірювань від пацієнтів через мобільний контент. Звідси дані можуть бути отримані органом, відповідальним за лікування, таким як власний лікар пацієнта (рис. 2). 


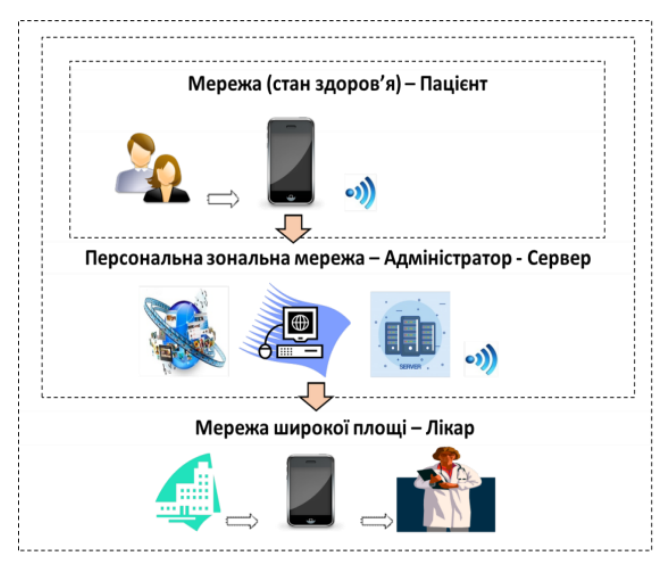

Рис. 2. Схема моніторингу, оцінки та прогнозу стану здоров'я пацієнтів.

Структурно-функціональні

особливості систем моніторингу та оцінки здоров'я пацієнтів:

- користувачі можуть вводити дані в систему через мобільний телефон;

- лікарі виписують пацієнтам ліки віддалено, i система може надсилати нагадування на мобільний телефон пацієнта;

- учасники мають змогу переглянути динаміку змін у своїх характеристиках та історії рецептів;

- систему можна налаштувати під будь-який інший додаток для віддаленого введення даних;

- моніторингова система також надає пацієнтові таку інформацію, як графіки лікування, інформацію про дози лікарських засобів, статистику, що стосується здоров'я.

Імплементацію моніторингових технологій контролю стану пацієнтів для населення територіальних громад можна розглянути на прикладі функціонування електронної системи дистанційного моніторингу здоров'я людини, запропоновану авторами А. Kotevski, N. Koceska and S. Koceski (2016) (рис. 3).

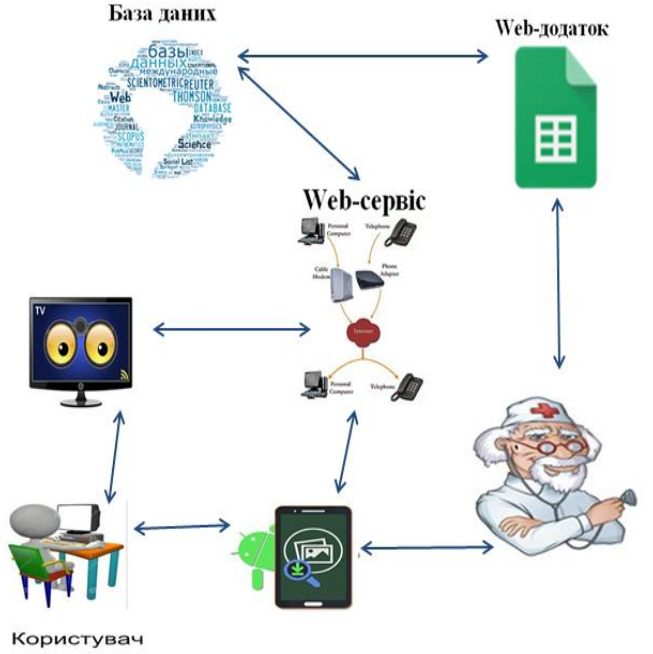

Рис. 3. Загальна архітектура електронної системи віддаленого моніторингу здоров'я пацієнтів (Aleksandar Kotevski, Natasa Koceska and Saso Koceski, 2016).

Дана електронна система моніторингу здоров'я пацієнтів складається 3 трьох модулів: $w e b$-сервіс, мобільний додаток та Smart-TV [17] (рис. 3). Ця система охоплює найважливіші ланки системи охорони здоров'я оскільки може зібрати необхідні життєво-важливі дані та зробити їх видимими для лікарів. Водночас, лікарі можуть працювати з базою даних з метою визначення засобів терапії та дистанційного лікування своїх пацієнтів [16, 17].

Для збору та візуалізації даних використовуються Open m-Health платформа, що забезпечує сумісність з іншими системами. Усі модулі використовують загальну базу даних (MS SQL). Мобільний додаток та Smart $T V$ використовують web-сервіси для взаємодії 3 базою даних. Web-програма доступна 3 кожного пристрою, який має підключення до Інтернету (рис. 3).

Слід відмітити, що електронні системи моніторингу здоров'я використовують основні фізіологічні дані для моніторингу життєдіяльності пацієнтів. До таких життєвих параметрів моніторингу, які використовуються для контролю стану здоров'я пацієнтів відносяться наступні дані: артеріальний тиск, частота серцевих скорочень, температура тіла, дихальний потік, цукор у крові, поточна вага, тощо. Важливим 
виступає той факт, що ці параметри необхідно регулярно (щодня, щотижня або щомісяця) контролювати 3 метою ефективного функціонування системи моніторингу здоров'я пацієнтів.

$W e b$-додаток має два типи користувачів: пацієнти та лікарі (рис. 3). Кожен пацієнт має доступ до власного профілю. Пацієнт може бачити ліки та дозування призначені лікарями, а також деяку інформацію, записки та поради. Він може вставляти значення контрольованих його параметрів, які вимірюються щодня. Лікарі мають повний доступ до всіх записів пацієнтів через необхідність режиму тривалого догляду за пацієнтом. Вони можуть додавати замітки та поради, прописувати ліки, пропонувати терапію, призначати зустрічі та надсилати внутрішні повідомлення пацієнтам. Вони також можуть переглядати дані, що вводяться пацієнтами, які стосуються їх життєво-важливих параметрів.

$W e b$-додаток

дозволяє

використовувати два типи представлення даних: табличний та графічний. У разі необхідності лікарі можуть використовувати ці дані в процесі прийняття рішень для призначення пацієнту нової терапії.

Мобільний додаток є другою частиною запропонованої системи (рис. 3). Він розроблений в Eclipse за допомогою мови програмування Java. Мобільний додаток має таку ж функціональність, як і web-додаток, що дозволяє отримувати доступ до даних пацієнтів з будь-якого місця та в будь-який час.

Додаток Smart TV розроблений за допомогою Samsung Smart SDK. Його може бути використане в умовах стаціонару для нагадування про щоденний прийом ліків вчасно або час звернення до лікаря. Додаток Smart TV показує сповіщення за 15 хвилин або за 1 годину до виду необхідної діяльності. Цей додаток був розроблений 3 ідеєю, що багато людей, залишаючись вдома, дивляться телевізор. Отже, використання платформи Smart TV для створення програми нагадування було ідеальним рішенням.
Особливості застосування webдодатків. Зважаючи на те, що більшість пацієнтів є особи старшого та похилого віку, велика увага приділяється дизайну інтерфейсу користувача. Після широкого аналізу інших подібних медичних застосувань та рекомендацій щодо дизайну, запропонованих у різних дослідницьких дослідженнях, був розроблений графічний інтерфейс для веб-мобільних та смарттелевізійних додатків. Для оптимізації графічного виводу та для зручності читання пацієнтів на екрані було застосовано великий розмір шрифту, контраст кольорів та достатню кількість порожніх пробілів серед тексту та графічних елементів.

Сценарій використання. Доступ до системи надається усім користувачам, які мають профіль у системі. Створення профілів користувачів та управління деякою загальною інформацією - - відповідальність адміністратора. Після створення профілів користувачі можуть увійти до програми за допомогою своїх облікових даних (надаються адміністратором). Пацієнт може використовувати веб- або мобільний додаток для вставки вимірюваних значень для керованих ними фізіологічних параметрів. Вiн може вибрати один 3 керованих параметрів, після чого подається відповідна форма для вставки значень. Пацієнт також може вибрати опцію, яка дозволяє написати записку лікарю.

Отже, використовуючи електронну систему моніторингу здоров'я пацієнтів лікарі можуть перевірити медичну документацію пацієнтів, запропонувати терапію або призначити ліки, використовуючи вебдодаток або мобільний додаток (рис. 3). Після вибору пацієнта зі списку пацієнтів лікарі також можуть бачити медичні записи пацієнтів. Дані, додані пацієнтами, можна подати у вигляді таблиці або графічно. Крім того, лікар може додати нові значення для деяких заздалегідь визначених медичних параметрів.

Таким чином, актуальність створення та застосування моніторингових технологій контролю здоров'я пацієнтів базується на 
можливостях віддаленого функціонування, що підвищують рівень медичної підтримки, яку отримує пацієнт у домашніх умовах. Це особливо важливо для пацієнтів із хронічними захворюваннями та пацієнтів, які потребують регулярного моніторингу життєвих показників. Використання веб- або мобільних додатків підвищує ефективність збору даних пацієнтів, одночасно забезпечуючи доступ до них 3 будь-якого місця, що вважається великою перевагою цього рішення, оскільки сприяє полегшенню спілкування між пацієнтами та лікарями.

Технічні можливості моніторингових технологій дозволяють охоплювати, впорядкувати та відображати дані пацієнтів за допомогою налаштованого для користувача інтерфейсу. Вчасний прийом ліків вважається основним пріоритетом для пацієнтів, оскільки це впливає на швидкість одужання та запобігає побічним ефектам, від порушень режиму прийому ліків. У цьому контексті дуже важливим $є$ використання програми Smart-TV для показу нагадувань та сповіщень. Також система моніторингу застосовує або регулярну оцінку стану людини або швидке втручання у випадку виявлення патології.

Підсумовуючи міжнародний досвід можна констатувати, що запропоновані системи дистанційного моніторингу та оцінки здоров'я пацієнтів орієнтовані на підвищення ефективності надання медичної допомоги за межами лікарень. Такий підхід дозволяє зменшити витрати та час поїздки до місця проживання пацієнтів, 3 одного боку, та покращення якості догляду за пацієнтами, з іншого.

\section{V. ЗАКЛЮЧЕННЯ}

\section{Визначальним фактором для} реформування системи охорони здоров'я на сучасному етапі розвитку країни виступає проблема якісної медичної допомоги, яка не завжди $\epsilon$ доступною для населення територіальних громад. Ключовим інструментом модернізації можуть виступати передові інформаційно-комунікаційні технології контроля стану здоров'я людини, ефективність впровадження яких доводить міжнародний досвід. Сучасні системи дистанційного моніторингу здоров'я пацієнтів інтегрують технології веб-, мобільного- та смарт-модулів для підвищення ефективності взаємодії між лікарями та пацієнтами, що сприяє оптимізації управляння системи охорони здоров'я у цілому. Слід зауважити, що дослідження, які належать до моніторингу здоров'я за допомогою "розумних" технологій надзвичайно перспективні, оскільки вони з'явилися для вирішення різних проблем сфери медицини, зокрема профілактики вікових хвороб та прискореного старіння населення.

\section{Інформаційно-комунікаційні}

технології контроля стану здоров'я пацієнтів можуть використовуватися для дистанційного моніторингу та оцінки здоров'я людей похилого віку, що проживають у сільській місцевості (зокрема територіальних громад), а також осіб с хронічними хворобами, які мають високий рівень медичної потреби.

\section{ПЕРЕЛІК ПОСИЛАНЬ}

[1] Харковлюк-Балакіна Н. В. Інформаційна оцінка та корекція забезпечення розумової працездатності людини в умовах впливу вікової інволюції / Н. В. Харковлюк-Балакіна, Ю. П. Горго // Медична інформатика та інженерія. - 2014. № 4. - С. $69-75$.

[2] Коваленко О. С. та ін. Мобільні застосунки у структурі сучасних медичних інформаційних систем / О. С. Коваленко, Л. М. Козак, О. О. Романюк, Т. А. Маресова, Л. В. Ненашева, Г. І. Финяк // Управляющие системы и машины. - 2018. № 4. - C. 57-69.

[3] Мінцер О. П. Основні вимоги до структури типових медичних інформаційних систем в управлінні охороною здоров'я / О. П. Мінцер, М. В. Банчук, І. А. Ярменчук, С. О. Дяченко // Медична інформатика та інженерія. - 2011. - № 2. C. $34-35$.

[4] Рогозинская Н. С., Козак Л. М. Информационная технология исследования состояния здоровья населения региона / Н. С. Рогозинская, Л. М. Козак // Управляющие системы и машины. - 2013. - №. 6. - С. 59 - 67.

[5] Bruno Silva et al. Mobile-health: A review of current state in 2015 / Bruno Silva, Joel Rodrigues, Isabel de la Torre Díez, Miguel López-Coronado, Kashif Saleem // Journal of Biomedical Informatics. August 2015. - 56. - P. 265 - 272.

[6] Булич Э., Муравов И. Факторы, определяющие здоровье человека / Э. Булич, И. Муравов // Вісник Харківського національного університету імені В. Н. Каразіна. Серія «Валеологія: сучасність і майбутнє» - 2016. - 20. - С. 37 - 48. [7] Arcelus A, Jones M., Goubran R, Knoefel F. Integration of Smart Home Technologies in a Health Monitoring System for the 
Elderly / A. Arcelus, M. Jones, R. Goubran, F. Knoefel // 21st International Conference on Advanced Information Networking and Applications Workshops (AINAW'07), Niagara Falls, Ont., 2007. - P. 820-825. DOI: 10.1109/AINAW.2007.209

[8] Ostmark Ake et al. Mobile medical applications made feasible through use of EISplatforms / Ake Ostmark et al. // IEEE Instrumentation and Measurement Technology conference proceedings. - Vol.1. IEEE; 1999, 2003.

[9] Hung Kevin and Yuan-Ting Zhang. Implementation of a WAP-based telemedicine systemfor patient monitoring / Kevin Hung and Zhang Yuan-Ting // Information Technology in Biomedicine, IEEE Transactions on 7.2. 2003. - P. $101-107$.

[10] Sorwar G, Hasan R. Smart-TV Based Integrated E-health Monitoring System with Agent Technology in 2013 / G. Sorwar, R. Hasan // 27th International Conference on Advanced Information Networking and Applications Workshops, Fukuokashi, Japan, 2012. - P. 406 - 411. DOI: 10.1109/WAINA.2012.155 [11] Chan Marie, Eric Campo and Daniel Estève. Assessment of activity of elderly people using a home monitoring system / Marie Chan, Eric Campo and Daniel Estève. // International Journal of Rehabilitation Research 28.1. - 2005. - P. $69-76$.
[12] Agarwal Sparsh and Chiew Tong Lau. Remote health monitoring using mobile phones andWeb services / Agarwal Sparsh and Chiew Tong Lau // Telemedicine and e-Health. - 2010. - 16.5. - P $603-607$.

[13] Yong L., Won J., Gilwon Y. Telemedicine and e-Health. October 2012. - 18(8). - P. 585 - 590.

[14] Sapal T, Wang X., Robert I, Song Y. Telemedicine. / T. Sapal, X. Wang, I. Robert, Y. Song // Journal and e-Health. - July 2004. - 9(3). -P. $247-257$.

[15] Silva Bruno et al. Mobile-health: A review of current state in 2015 / Silva Bruno et al. // Journal of biomedical informatics. -2015 . -56 . - P. $265-272$.

[16] Jiuping $\mathrm{Xu}$ and Lei $\mathrm{Xu}$. Sensor System and Health Monitoring in Integrated System Health Management. - 2017. $472 \mathrm{p}$.

[17] Kotevski A., Koceska N. and Koceski S. E-health monitoring system / A. Kotevski, N. Koceska and S. Koceski // International Conference on Applied Internet and Information Technologies. - 2016. - P 259 - 263. DOI:10.20544/AIIT2016.32

\title{
ИМПЛЕМЕНТАЦИЯ МОНИТОРИНГОВЫХ ТЕХНОЛОГИЙ КОНТРОЛЯ СОСТОЯНИЯ ЗДОРОВЬЯ ПАЦИЕНТОВ ДЛЯ НАСЕЛЕНИЯ ТЕРРИТОРИАЛЬНЫХ ОБЩИН
}

\author{
Харковлюк-Балакина Н. В., к.б.н. \\ natabalakina74@meta.ua \\ ГУ "Институт геронтологии им. Д. Ф. Чеботарева НАМН Украины" \\ г. Киев, Украина \\ Горго Ю. П., профессор, д.б.н. \\ yugorgo@ukr.net \\ Национальный технический университет Украины \\ "Киевский политехнический институт им. Игоря Сикорского" \\ г. Киев, Украина \\ Медвидчук К. В. \\ kvastrin@gmail.com \\ ГУ "Институт геронтологии им. Д. Ф. Чеботарева НАМН Украины" \\ г. Киев, Украина
}

\begin{abstract}
Реферат - Определены ведущие позищии, касающиеся контроля здоровья населения территориальных громад. Обоснована эффективность использования передовых информационно-коммуникационных технологий дистанционного мониторинга состояния здоровья паџиентов для лии, проживающих в сельской местности, а также лии, с хроническими патологиями, имеющих высокий уровень медицинской потребности. Изучен опыт использования "умных" технологий в медицинской отрасли для решения задач профилактики возрастных патологий и ускоренного старения населения.
\end{abstract}

Ключевые слова - системы дистанционного мониторинга здоровья пациентов, информационно-коммуникационные технологии в медицине, контроль здоровья, управления здравоохранением на региональном уровне. 
UDC 614.2:364.46:331.446.3

\title{
IMPLEMENTATION OF MONITORING TECHNOLOGIES FOR PATIENT HEALTH CONTROL FOR THE POPULATION OF TERRITORIAL COMMUNITIES
}

Kharkovliuk-Balakina N.V., Ph.D. natabalakina74@meta.ua

Dmitry F. Chebotarev Institute of Gerontology of the National Academy of Medical Sciences of Ukraine Kyiv, Ukraine

Gorgo Y. P., Professor, Dr. Sci. yugorgo@ukr.net National Technical University of Ukraine "Igor Sikorsky Kyiv Polytechnic Institute"

Kyiv, Ukraine Medvydchuk K. V. kvastrin@gmail.com

Dmitry F. Chebotarev Institute of Gerontology of the National Academy of Medical Sciences of Ukraine Kyiv, Ukraine

\begin{abstract}
Leading positions on health control of the population of territorial communities have been identified. The effectiveness of the use of advanced information and communication technologies for remote monitoring of patients' health for people living in rural areas, as well as people with chronic pathologies who have a high level of medical needs was substantiated. The experience of using "smart" technologies in the medical field to solve problems of prevention of age-related diseases and accelerated aging was studied.
\end{abstract}

Key words - systems for remote monitoring of patients' health, information and communication technologies in medicine, health control, health management at the regional level. 